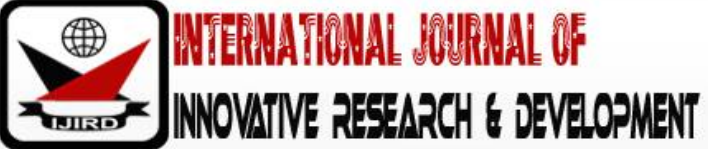

ISSN 2278-0211 (Online)

\section{Determination of Bacteriological and Physical Quality and Safety of Bottled and Sachet Water Produced in Okitipupa Local Government Area of Ondo State, Nigeria}

\author{
Adetuwo, Olagunju Johnson \\ Postgraduate Student, Department of Microbiology, \\ Adekunle Ajasin University, Akungba-Akoko, Nigeria
}

\begin{abstract}
:
Purpose: This study was carried-out with aim to determine the bacteriological and physical quality and safety of locally produced bottled and sachet drinking water sold for public consumption in Okitipupa Local Government Area of Ondo State, Nigeria. Methods: Total of nine samples of bottled water from three brands and twenty-one samples of sachet water from seven brands purchased randomly were analyzed for bacteriological contamination (total coliform count and faecal coliform count per $100 \mathrm{ml}$ ) using membrane filtrate method and reported in term of cfu/100 ml. While physical parameters; $p H$, turbidity, odour and colour were analysed with standard laid down protocols. Findings: Both bottled water and sachet water were not contaminated with faecal coliform. All $(100 \%, 21 / 21)$ of the sachet water and (100\%, 9/9) of bottled water analyzed were within acceptable limits of 10 total coliforms per $100 \mathrm{ml}$ set by WHO and the Nigeria drinking water standards (NIS). The physical quality (turbidity, colour, odour and pH) of all the sachets and bottles water brands analyzed were within the acceptable limits. There was statistically significant difference between the median count of total coliform in both sachet water and bottled water brands $((2)=1.80=$ 0.5012). Both bottled water and sachet water were not contaminated with faecal coliforms; But few of sachets water were contaminated with total coliform still below acceptable limits though. Recommendations: Government and other regulatory agencies should intensify surveillance activities and enforce strict hygienic measures in this rapidly grow industry to improve good manufacturing practice of bottled and sachet water production as this will go a long way to enhance public health safety.
\end{abstract}

Keywords: PH, Turbidity, odour, colour, bacteria, safety, quality

\section{Introduction}

Most waterborne disease is preventable given basic hygiene and sanitation, but these two factors are critical and possible only through provision of potable water in form Sachet Water and bottled water commonly called 'packaged water'. Packaged water is any potable water that is manufactured or processed for sale which is sealed in food-grade bottles, sachets, or other containers and intended for human consumption (WHO). Sale of packaged water has exploded all over the world in recent years, largely as a result of public perception that it is safe, tastes better, and has a better quality compared to raw tap water (Dodoo, et al., 2006; Bitton, 2005). The increment in consumption globally could also be due to a result of an increase in per capital use as well as population growth (Daniel and Daodu, 2016). Even in countries where tap water quality is considered excellent, demand was so high, making packaged water the fastest growing product of the nonalcoholic beverage market worldwide (Harley and Prescott, 2002; Nsanse, et al., 1999). The above situation is not any different in the study area, Okitipupa and all over Nigeria where water packaged in bottles and polythene bags has become a very common consumer product most especially in the urban centres. The high demand may attract sub-standard products and counterfeits into the market. With this increase in consumption of packaged water, there is a possibility of producing products that are not fit for human consumption because of monetary interests (Edema, Atayese, and Bankole, 2011; Afiukwa, et al., 2010). Access to safe drinking water is still one of the major challenges of the 21st century (Ehiowemwenguan, Iloma, and Adetuwo, 2014; Bitton, 2005). Unsafe water is a global public health threat, placing persons at risk for a host of diarrhoeal diseases as well as chemical intoxication (Afiukwa, et al., 2010; World Health Organization, 2019). Although disease outbreaks due to contaminated packaged water are not common, any possible contamination may lead to widespread epidemic because of the high demand and consumption. Before water can be described as potable, it has to comply with certain physical, chemical and microbiological standards which are designed to ensure that the water is indeed potable and safe to drink (Akpborie and Ehwarimo, 2012; Semerijian, 2011; Raj, 2005). A Potable water is the water that is free from water borne pathogens and chemical substances harmful to health. Good quality Water is major factor in guaranteeing public health safety and for sustainable human development. Water related disease has become great burden to the society and no one can accurately measure the true burden of waterborne disease (Daniel and Daodu, 2016). There are multiple routes of transmission of most infectious agents that can be transmitted 
directly from water including direct ingestion, ingestion of contaminated food, and secondary transmission through the fecal-oral or oral-oral route. However, it is increasingly apparent that many waterborne agents can also be transmitted through aerosols and dermal contact. The greatest problem to determining the burden of waterborne disease is the lack of surveillance data (Geldreich, 1996; Dada, 2011). The majority of cases of gastrointestinal disease are never reported, and this includes deaths from many of the diarrheal diseases, particularly in the poorest regions of the world (WHO, 2019). Even in the relatively limited number of cases where health care is sought, most disease remains undiagnosed, misdiagnosed, and/or never reported to a centralized surveillance system. The World Health Organization (WHO) report that on a global scale, $88 \%$ of cases of diarrhea are the result of poor hygiene and sanitation, including unsafe water, and are therefore preventable (WHO, 2019). They also estimate that these cases of diarrheal disease result in 1.5 million deaths per year, primarily among children (WHO, 2019) Monitoring and detection of indicator and disease-causing microorganisms in water are a major part of Water sanitary microbiology (Willey, et.al., 2008; Berger and Oshiro, 2002). A wide range of viral, bacteria, and protozoan diseases result from contamination of water with human and other animals' fecal wastes (Raj, 2005). This contamination may be as a result unwashed hands after defecation, leaching of soak away to water source or poor implementation of HACCP procedures during potable water production. Many of the pathogens that are because waterborne diseases can be detected directly by using indicator organisms as index of possible water contamination by human pathogens. Because of the importance of water to life and the high level of water contamination by microorganisms, microbial quality of potable water has become essential aspect of sanitary analysis of water (Daniel and Daodu, 2016; Dada, 2011).

\section{Materials and Methods}

\subsection{Sample Collection}

Bottled and sacbdt water samples produced in selected towns and locations within Okitipupa Local Government Area were purchased in triplicate from each 'pure water' producer, thirty samples were bought. All the samples were retained in their original sealed containers and clearly marked for identification with letters from A to I for bottled water and from 1 to 21 for sachet water samples. They were transported to Department of Microbiology Laboratory, Adekunle Ajasin University, Akungba-Akoko, Nigeria in a sample carrier containing ice packs and analysed within 4 to 6 hours of collection. Glassware or materials used in this experiment were washed with distilled water and then autoclaved at $121^{\circ} \mathrm{C}$ for 15 minutes to ensure sterility.

\subsection{Bacteriological Analysis}

Bacteriological characteristics were determined as described by Willey, et.al. (2008) and Harley and Prescott. (2002). The presence-absence test (P-A test) was used for presumptive test for coliforms and confirmed by Colilert defined substrate test. The membrane filter technique with trapped bacteria is transferred to the surface of nutrient agar (NA), Salmonella-Shigella agar, Thiosulphate citrate bile salt sucrose agar to determine. Salmonella, Shigella, and Vibrio cholerae respectively. All plates were incubated at 35oC for 24 hours. Presumptive colonies were confirmed by Gram staining and biochemical test kits (API). Each plate was given a positive or negative score. The analysis for the bacteriological quality of the packaged water was determined by comparing it with the NIS and WHO standards for packaged water which requires water samples of good quality to be with 10 coliforms per $100 \mathrm{ml}$ of water, and 0 faecal coliform organisms per $100 \mathrm{~mL}$ was reported in terms of $\mathrm{cfu} / 100 \mathrm{ml}$.

\subsection{Characterization and Identification of Bacteria Isolates}

Bacteria isolates were identified and characterized according to Bergy's manual of systematic determinative Bacteriology by Buchanan, et al., (1974).

\subsection{Physical Analysis}

Turbidity was measured using turbidity tubes and reported in NTU and $\mathrm{pH}$ using Wagtech $\mathrm{pH}$ meter (Ehiowemwenguan, Iloma, and Adetuwo, 2014). The equipment was calibrated before use. The physical quality of the packaged water was determined by comparing it with the Nigeria and WHO standards for packaged water which requires water samples of good quality to be with $\mathrm{pH}$ and turbidity of $<5 \mathrm{NTU}$ and $\mathrm{pH}$ of $6.5-8.5$, respectively. Furthermore, the colour of packaged water samples was analysed by colour unit's method using $0.5 \mathrm{~g} / \mathrm{dm}^{3}$ of potassium Chloroplatinate diluted with $50 \mathrm{ml}$ water samples respectively in Nessler tubes. The water odour was analyzed using threshold odour number this was done by adding $50 \mathrm{ml}$ of volume of water with odour with $50 \mathrm{ml}$ of sample water with no odour. Then threshold odour number was calculated out.

\subsection{Statistical Analysis}

Data was entered using SPSS version 20.01v computer software for analysis. Data was analysed using both descriptive and inferential statistics. For the descriptive statistics, frequencies and cross tabulations were generated. The main outcome was bacteriological quality of the packaged water (presence or absence of either total coliform or faecal coliform). Other outcomes were turbidity level (within the acceptable limits or not) and pH (within the acceptable limits or not). The strength of association was determined using odds ratio and $\mathrm{p}<0.05$ values at $95 \%$ level of confidence. The statistical significance difference between the quality of sachet and bottled water samples was tested by using MannWhitney U test $(\mathrm{p}<0.05)$. 


\section{Results and Discussion}

\begin{tabular}{|c|c|c|c|c|c|}
\hline Sample & Ph & $\begin{array}{c}\text { Turbidity } \\
\text { (NTU) }\end{array}$ & Odour (TON) & Colour (CU) & $\begin{array}{c}\text { Total Suspended } \\
\text { Solids(Mg/L) }\end{array}$ \\
\hline Bottles & 6.8 & 0.0 & $\mathrm{U}$ & 0 & $\mathrm{NS}$ \\
\hline Sachets & 7.2 & 0.0 & $\mathrm{U}$ & 0 & $\mathrm{NS}$ \\
\hline Nigeria standard (NIS) & $6.5-8.5$ & 5 & $\mathrm{U}$ & 0 & $\mathrm{NS}$ \\
\hline WHO standard & 6.5 & $0-5$ & 3 & $0-15$ & $\mathrm{NS}$ \\
\hline
\end{tabular}

Table 1: Shows Mean Values Results of Physical Analysis of Bottled and Sachet Water Samples

\subsection{Results Show Mean Value of the Analysed Samples}

NTU = nephelometric turbidity units,

TON = threshold odour number,

$\mathrm{CU}=$ colour units.

$\mathrm{U} \quad=$ no odour detected, $0=$ colourless, $\mathrm{NS}=$ no suspended solid.

The physical properties of packaged water showed that $\mathrm{pH}$ was between the ranged of 6.2 and 7.2 and turbidity was 0.0. These results were within the permissible limits of $\mathrm{pH}$ and turbidity, which indicate that packaged water was suitable for human consumption. These results are similar to studies conducted in Zaria, Ibadan, and Benin-city, Nigeria (Ugochukwu, Giwa, and Giwa, 2015; Oyedeji, Olutiola and Moninuola, 2016; Daniel and Daodu, 2016). However, these results contradict results from studies carried out in Ghana and Tanzania which showed pH values for sachet water ranging from 5.3 to 7.9 (Dodoo et al., 2006; Kassenga, 2007) and in Lebanon, from 6.3 to 7.9(Semerijian, 2011).Which implies that some of the packaged water was not suitable for human consumption due to higher acidity. Another study carried out in Warri, Delta and in some south Eastern Nigeria shown that package water has higher pH and turbidity compared to what was observed in this study (Akpoborie and Ehwarimo, 2012; Afiukwa, et al., 2010).

\begin{tabular}{|c|c|c|c|c|}
\hline Samples & $\begin{array}{c}\text { Total faecal } \\
\text { coliform count } \\
\text { (cfu/100ml) }\end{array}$ & $\begin{array}{c}\text { Total } \\
\text { coliform } \\
\text { count(cfu/100ml) }\end{array}$ & $\begin{array}{c}\text { Salmonella- } \\
\text { Shigella } \\
\text { count(cfu/100ml) }\end{array}$ & $\begin{array}{c}\text { Vibrocholerae } \\
\text { count(cfu/100ml) }\end{array}$ \\
\hline Sachet water & 0 & 6 & ND & ND \\
\hline Bottled water & 0 & 3 & ND & ND \\
\hline $\begin{array}{c}\text { Nigeria standard } \\
\text { (NIS) }\end{array}$ & 0 & 10 & 0 & 0 \\
\hline WHO standard & 0 & 10 & 0 & 0 \\
\hline
\end{tabular}

Table 2: Shows Results of Bacteriological Analysis of Sachets and Bottles Water Samples

0 Means No Growth, ND Means No Gas Detected

Majority of the sachet water samples (71.4\%) and bottled water samples (66.7) analysed showed negative growth for total coliform. While few of the sachet water samples (28.6\%) and bottled water samples (33.3) analysed shown positive growth for total coliform but still within acceptable levels of $10 \mathrm{cfu} / 100 \mathrm{~mL}$ of water set by WHO and NIS. Also, still lower than most probable number (MPN) of total coliform observed by similar research conducted by other researchers (Oyedeji, Olutiola and Moninuola, (2016); Kassengh, (2007); Thliza, et al., (2015); Ugochukwu, Giwa and Giwa, (2015. Three out of seven sachet water (42.9\%) and one out of three bottled water (33.3\%) brands had total coliform count but within the acceptable limit of $10 \mathrm{cfu} / 100 \mathrm{~mL}$ as shown in Table 2 . The odds of sachet water being likely to be contaminated with total coliform were two times higher when compared to bottled water $(\mathrm{OR}=1.8, \mathrm{CI}$ : $0.75-1.37)$ as shown in Table 4. The bacterium isolated from sachet water samples in this work was Escherichia coli. Table 2 also shown that no Salmonella species, Shigella species nor Vibrio cholerae were isolated from any of the water samples analysed. This is an indicative that sachet and bottled water samples analysed were free from pathogenic bacteria. This result agreed with the study conducted by Augustine, et.al, (2019) and Yusuf, et al., (2016) in Ibadan and Zaria respectively.

\begin{tabular}{|c|c|c|c|c|c|c|c|}
\hline Parameters & Median & Std. Deviation & Range & Max. & Min. & \multicolumn{2}{|c|}{ Standards } \\
\hline Bottled water & & & & & & WHO & National \\
\hline Total coliform & 0.0 & 0.5 & 1.0 & 1.0 & 0.0 & 0 & 0 \\
\hline Faecal coliform & 0.0 & & & & & & \\
\hline pH & 6.8 & 0.32 & 0.5 & 7.2 & 6.7 & $<8.0$ & $6.5-8.5$ \\
\hline Turbidity & 0.0 & 0.0 & 0.0 & 0.0 & 0.0 & $<5$ & $<5$ \\
\hline $\begin{array}{c}\text { Sachet water } \\
\text { Total coliform }\end{array}$ & 0.0 & 0.34 & 3.0 & 3.0 & 0.0 & 0 \\
\hline Faecal coliform & 0.0 & 0.0 & 0.0 & 0.0 & 0.0 & 0 & 0 \\
\hline pH & 7.0 & 0.33 & 1.1 & 7.6 & 6.5 & $<8.5$ & $6.5-8.5$ \\
\hline Turbidity & 0.0 & 0.0 & 0.0 & 0.0 & 0.0 & $<5$ & $<5$ \\
\hline
\end{tabular}

Table 3: Descriptive Statistics of the Total Coliform Count, Ph, and Turbidity in Packaged Water Brands 


\begin{tabular}{|c|c|c|c|c|}
\hline Variable & Bottled Water $(\boldsymbol{n = 0 9 )}$ & Sachet Water $(\boldsymbol{n = 2 1 )}$ & $\begin{array}{c}\text { Odds Ratio } \\
\text { (Fisher's Exact Test) }\end{array}$ & 95\% CI \\
\hline $\begin{array}{c}\text { Total coliform } \\
\text { Present }\end{array}$ & Number $(\%)$ & Number $(\%)$ & 1.80 & $0.75-1.37$ \\
\hline Absent & $03(33.3)$ & $06(28.5)$ & & \\
\hline Total & $6(66.7)$ & $15(71.4)$ & & \\
\hline
\end{tabular}

Table 4: Association between Packaging Materials for Drinking Water and Total Coliform

Occurrence in Packaged Water

\section{Conclusion}

In conclusion, waterborne diseases pose very serious threats to society. Two of the twenty-one sachet water studied may constitute health risk to immunocompromised individual because $5 \mathrm{cfu} / 100 \mathrm{ml}$ of E. coli was isolated from them, although the value still within acceptable level of total coliform permitted in drinking water.

\section{Recommendations}

Government and other regulatory agencies should intensify surveillance activities and enforce strict hygienic measures in this rapidly grow industry to improve good manufacturing practice of potable water production as this will go a long way to enhance public health safety.

\section{Reference}

i. Afiukwa, N.F., Iroha, I.R., Afiukwa, C.A., Ayogu, T.E., Onwa, N.C. and Nwuzo, A.C. (2010). Presence of antibiotic resistant coliforms in sachet water sold in some parts of South Eastern Nigeria. Journal of Microbiology and Antimicrobials, 2(5). 51-54.

ii. Akpoborie, I.A. and Ehwarimo, A. (2012). 'Quality of packaged drinking water produced in Warri Metropolis and potential implications for public health'. Journal of Environmental Chemistry and Ecotoxicology, 4(11). $195-202$.

iii. Augustine, A.I., Ogbonnaya, E., Olaide, O.A., Emmanuel, O.O., Uloaku, O., and Davidson, O. (2019). Assessment of Sachet and Bottled water quality in Ibadan. Global Journal of Nutrition and Food.ISSN 2644-2981.

iv. Berger, P.S., and Oshiro, R.K. (2002). Source water protection: Microbiology of source water, pp2967-2978. In: Encyclopedia of Environmental Microbiology. G. Bitton, Editor-in-chief, Wiley InterScience, New York.

v. Bitton, G. (2005). Wastewater microbiology. $3^{\text {rd }}$ Edition. Wiley series in ecological and Applied Microbiology. ISBN 0471650714(2).4.

vi. Buchanan, R.E., Gibbons, N.E., Cowan, S.T., Holt, T.G. and Liston, J. (1974). Bergey's manual of determinative bacteriology (Williams and Wilkinns Co., Baltimore), 1246.

vii. Daniel, E.O., and Daodu, A.A. (2016). Bacteriological Analysis of Sachet water Vended in UGBOR, Benin City, Nigeria. https//www.researchgate.net/publications/322023981.

viii. Dodoo, D.K., Quagraine, E.K., Okai-Sam, F., Kambo, D.J., and Headley, J.V. (2006)'Quality of 'sachet' waters in the Cape Coast municipality of Ghana,' Journal of Environmental Science and Health-Part A: Toxic/Hazardous Substances and Environmental Engineering 41(3): 329-342.

ix. Edema, M.O., Atayese, A.O. and Bankole, M.O. (2011). 'Pure water syndrome: Bacteriological quality of Sachetpacked drinking water sold in Nigeria'. African Journal of Food, Agriculture, Nutrition and Development, 11(1). 4595-4609.

X. Ehiowemwenguan, G., Iloma, A.O., and Adetuwo, J.O. (2014). Physico-Chemical and Bacteriological Quality of Bore-hole Water in Eyaen Community Area of Edo State, Nigeria. International Journal of Basic and Applied Science. 03(02): 66-68. 11.

xi. 11.Geldreich, E.E. (1996). Microbial Quality of Water Supply in Distribution Systems, Water Quality-Management (1st edition) edited by B. Raton, CRC Press, New York, NY, USA.

xii. Harley, J. P. and Prescott, L. M. (2002). Laboratory Exercises in Microbiology. 5th Edition. Mac Graw Hill, New York.

xiii. Dada, A.C. (2011).'Packaged water: optimizing local processes for sustainable water delivery in developing nations,' Globalization and Health7: 24.

xiv. Kassenga, G.R. (2007).'The health-related microbiological quality of bottled drinking water sold in Dar es Salaam, Tanzania,' Journal of Water and Health, vol. 5, no. 1, pp. 179-180.

xv. Nsanze, H., Babarinde, Z., and Al Kohaly, H. (1999). 'Microbiological quality of bottled drinking water in the UAE and the effect of storage at different temperatures, 'Environment International 25:(1) 53-57.

xvi. Oyedeji, O., Olutiola, P.O., and Moninuola, M.A. (2016). 'Microbiological quality of packaged drinking water brands marketed in Ibadan metropolis and Ile-Ife city in South Western Nigeria,' African Journal of Microbiology Research 4 (1): 096-102.

xvii. Raj, S.D. (2005). 'Bottled water: how safe is it?' Water Environment Research 77(7): 3013-3018.

xviii. 18.. Semerjian, L.A. (2011). 'Quality assessment of various bottled waters marketed in Lebanon,' Environmental Monitoring and Assessment 172(1)4: 275-285. 
xix. 19. Thliza, I.A., Khan, A.U., Dangora, D.B., and Yahaya, Y. (2015) 'Study of bacteriological load of some brands of sachet water sold in Ahmadu Bello University (Main Campus), Zaria, Nigeria,' International Journal of Current Science 14: 91-97.

xx. 20.. Ugochukwu, S.F., Giwa, J., and Giwa, A. (2015). 'Bacteriological evaluation of sampled sachet water sold in Samaru-Zaria, Kaduna State, Nigeria,' Nigerian Journal of Basic and Clinical Sciences 12(1): 6-12.

xxi. 21. Willey, J.M., Sherwood, L.M., and Woolverton, C. J. (2008). Prescott, Harley and Klein's Microbiology. MC Gram Hill, New York, USA. pp 1050-1054.

xxii. 22. World Health Organization (2019). Fact sheets on drinking Water.https://www.who.int/news-room/factsheets/details/drinking-water. Accessed on March 10th, 2020.

xxiii. 23. Yusuf, Y.O, Jimoh, A.I., Onaolupo, E.O., and Dabo, Y. (2016). An Assessment of sachet water quality in Zaria Area of Kaduna State. Academic Journals.8(7):174-180. 